\title{
DETERMINATION OF in vitro BIOFILM FORMATION ABILITIES OF FOOD BORNE Salmonella enterica ISOLATES
}

\author{
Deniz AKSOY \\ Trakya University, Faculty of Science, Department of Biology, Edirne TURKEY \\ ORCID ID: orcid.org/0000-0001-8696-9725, e-mail: denizyuksel@trakya.edu.tr
}

Cite this article as:

Aksoy D. 2019. Determination of in vitro Biofilm Formation Abilities of Food Borne Salmonella enterica Isolates. Trakya Univ J Nat Sci, 20(1); 5762, DOI: $10.23902 /$ trkjnat.471236

Received: 16 October 2018, Accepted: 18 March 2019, Online First: 19 March 2019, Published: 15 April 2019

\begin{abstract}
Salmonellosis caused by non-typhodial Salmonella enterica serotypes is one of the most important food-borne diseases worldwide and biofilm structure formed by these pathogens provide a reservoir for food contamination and a source for infections. This study was performed in order to determine biofilm formation abilities of food borne Salmonella isolates on polystyrene and on air liquid interphase and their colony morphologies when grown on Congo Red Agar plates. 32 food-borne Salmonella strains isolated from retail chicken carcasses in Edirne province of Turkey and belonging to the Infantis, Enteritidis, Kentucky and Telaviv serotypes were used. The microtiter plate technique was used to determine biofilm formation abilities of the isolates on polystyrene surfaces by measuring the optical density (OD) values of the stained bacterial biofilms. The results showed that the strongest biofilm formation capacities of the isolates were observed at $22^{\circ} \mathrm{C}$ for 3 days of incubation. Although all isolates formed pellicle on the liquid-air interface at $22^{\circ} \mathrm{C}$, only $13 \%$ of the isolates belonging to the Infantis, Kentucky and Enteritidis serovars formed pellicle at liquid-air interface at $37^{\circ} \mathrm{C}$. Three different colony morphotypes (saw; smooth and white, bdar; brown, dry and rough, rdar; red, dry and rough) were determined on Congo Red Agar among the isolates. High biofilm formation abilities of the tested Salmonella isolates can lead to widespread of virulence and resistance properties, especially to medically important antibiotics such as ciprofloxacin, via food chain. This situation constitutes an important concern for public health.
\end{abstract}

Key words: Salmonella, biofilm, food-borne pathogen, microbial food safety.

Özet: Salmonella enterica serotiplerinin neden olduğu salmonelloz vakaları dünya çapında en önemli gıda kökenli hastalıkların başında gelmektedir. Bu patojenlerin oluşturduğu biyofilm yapısı hem gıda kontaminasyonlarına neden olmakta hem de enfeksiyonlar için kaynak oluşturmaktadır. Bu çalışmada gıda kökenli Salmonella enterica izolatlarının polistirende ve havasıvı ara fazında biyofilm oluşturma yetenekleri ve ayrıca Kongo kırmızısı agar plakalarında koloni morfolojilerinin belirlenmesi amaçlanmıştır. Çalışmada Edirne ilinde satışa sunulan tavuk karkaslarından izole edilmiş 32 adet Salmonella izolatı kullanılmıştır. İzolatların plastik yüzeylerdeki biyofilm oluşturma yeteneklerinin belirlenmesinde boyanmış bakteriyel biyofilmlerin optik yoğunluklarının ölçülmesi esasına dayanan mikroplaka tekniği kullanılmıştır. Polistren plakalardaki biyofilm oluşturma sonuçlarına göre, izolatların en güçlü biyofilm oluşturma kapasitesi $22^{\circ} \mathrm{C}^{\prime} \mathrm{de} 3$ günde gözlemlenmiştir. Bütün izolatlar $22^{\circ} \mathrm{C}^{\prime} \mathrm{de}$ sıvı-hava ara fazında pelikül oluştururken izolatların sadece \% 13'ü (Infantis, Kentucky ve Enteritidis serovarlarını içeren) $37^{\circ} \mathrm{C}^{\prime} \mathrm{de}$ sıvı-hava ara fazında pelikül oluşturmaktadır. Kongo kırmızısı agarda üç farklı koloni morfolojisi (saw; pürüzsüz ve beyaz, bdar; kahverengi, kuru ve pürüzlü, rdar; kırmızı, kuru ve pürüzlü) belirlenmiştir. Salmonella izolatlarının yüksek biyofilm oluşturma kapasiteleri, virülens ve özellikle tıbbi olarak önemli antibiyotikleri içeren direnç faktörlerinin gıda zinciri yolu ile geniş çaplı yayılımına neden olabilir. Bu durum halk sağlığı açısından büyük bir endişe kaynağı oluşturmaktadır.

\section{Introduction}

Salmonellosis caused by non-typhodial Salmonella enterica serotypes is one of the most important foodborne diseases worldwide and an increasing number of human Salmonellosis cases have been linked to consumption of contaminated food (Panisello et al. 2000). Poultry and poultry associated products in particular are essential reservoirs for food-borne pathogens and these products have been identified as significant transmission vehicle for Salmonellosis by allowing Salmonella to be easily transmitted to humans from these products

(Hoelzer et al. 2011, Antunes et al. 2016). It is also known that many pathogenic bacteria including Salmonella can attach to and grow on food and food contact surfaces to form biofilms in food processing industry which cause major economic and public health concerns and this biofilm formation ability can be the main reason of wide distribution of Salmonella isolates (Vestby 2009b). Biofilm formation depends on some characteristics of the bacteria and environmental factors such as $\mathrm{pH}$, temperature and nutrient components (Shia \& Zhu 2009). 
Bacterial biofilms are highly resistant to environmental stress, antibiotics, and disinfectants and thus are difficult to sanitate (Hoiby et al. 2010, Steenackers et al. 2012). Biofilms constitute a source for clinical infections and pathogenic microorganisms in biofilms provide a reservoir for food contaminations (Costerton et al. 1999, Srey et al. 2013).

In the present study, biofilm formation abilities of food borne Salmonella isolates on an abiotic surface (polystyrene plate) were investigated. The tests were performed at three different incubation temperatures and times to determine how these variables affected biofilm formation by the isolates. The pellicle formation on air liquid interphase was also tested as an indication of biofilm formation. In addition, colony morphologies of the isolates on Congo Red Agar plates were evaluated to reveal the components of biofilm produced considering morphotypes on the agar plates.

\section{Materials and Methods}

\section{Bacterial strains}

Salmonella strains formerly isolated from retail chicken carcasses in Edirne province of Turkey were used (see Aksoy and Şen 2015). The strains were determined to belong to the Infantis $(n=26)$, Enteritidis $(n=4)$, Kentucky $(n=1)$ and Telaviv $(n=1)$ serotypes. The original codes assigned to the serotypes (from A1 to A32) were used throughout the text when it was necessary to refer to the serotypes individually.

\section{Biofilm formation on polystyrene}

96-well polystyrene microplates (Grenier Bio-One) were used for quantification of biofilm production based on the previously described method with some modifications (Stepanović et al. 2004). The wells were filled with $230 \mu \mathrm{L}$ of $\mathrm{LB}^{\text {wo }} / \mathrm{NaCl}$ broth. Liquid bacterial cultures (18 h old) were diluted in $\mathrm{LB}^{\mathrm{wo}} / \mathrm{NaCl}$ broth to OD570 $=0.2$ and $20 \mu \mathrm{L}$ of these cultures were transferred to each well (three parallels of each strain). The negative control wells contained broth only. Microplates were incubated statically for one $(24 \mathrm{~h})$, two $(48 \mathrm{~h})$ and three days $(72 \mathrm{~h})$ at $5^{\circ} \mathrm{C}, 22^{\circ} \mathrm{C}$ and $37^{\circ} \mathrm{C}$. The incubation temperatures were selected to represent routine storage condition of foods, room temperature and optimum growth condition of Salmonella, respectively. After incubation, the contents of the wells were emptied, wells were washed three times with $300 \mu \mathrm{L}$ sterile distilled water and then $250 \mu \mathrm{L}$ of methanol $(\geq 99.9 \%)$ was added per well. After incubation for $15 \mathrm{~min}$ in room temperature, microplates were emptied and air dried. Then wells were stained with Cyristal violet $(0.1 \%)$ used for Gram staining (Merck) for 5 min. Excess stain was rinsed off by washing the microplates with running tap water and the microplates were air dried. The dye bound to adherent cells was dissolved using $250 \mu \mathrm{L}$ of $33 \%$ (v/v) glacial acetic acid in each well. The optical density was measured at $570 \mathrm{~nm}$ using a Multiskan EX reader (Bio-Rad). Based on the OD results, strains were classified into four categories as no biofilm producers, weak, moderate or strong biofilm producers as previously described (Stepanović et al. 2000). The cut-off optical density (ODc) is defined as three standard deviations above the mean OD of the negative control. Strains were classified as follows: $\mathrm{OD} \leq \mathrm{ODc}=$ no biofilm producer, $\mathrm{ODc}<\mathrm{O} . \mathrm{D}$. $\leq(2 \times$ ODc $)=$ weak biofilm producer, $(2 \times$ ODc $)<$ OD $\leq$ $(4 \mathrm{x}$ ODc $)=$ moderate biofilm producer and $(4 \mathrm{x}$ ODc $)<$ $\mathrm{OD}=$ strong biofilm producer.

\section{Pellicle formation at liquid-air interface}

The pellicle formation at the liquid-air interface was tested by inoculation of $0.5 \mathrm{~mL}$ of bacterial cultures $(18 \mathrm{~h})$ in $4.5 \mathrm{~mL} \mathrm{LB}{ }^{\text {wo }} / \mathrm{NaCl}$ for incubation at $5^{\circ} \mathrm{C}, 22^{\circ} \mathrm{C}$ and $37^{\circ} \mathrm{C}$ for eight days in static conditions. The strains were visually controlled every day for presence of pellicle formation (Solano et al. 2002). S. Typhimurium ATCC 14028 was used as the positive control.

\section{Colony morphology on Congo Red (CR) Agar plates}

The method described by Turki et al. (2012) was used with some modifications for determination of colony morphology. Bacterial cultures (18 h old) were plated on LB wo $/ \mathrm{NaCl}$ agar supplemented with Congo Red (8 $\mu \mathrm{g} / \mathrm{mL}$ ). After incubation at $5^{\circ} \mathrm{C}, 22^{\circ} \mathrm{C}$ and $37^{\circ} \mathrm{C}$ for eight days, the colony morphology was determined based on the classification as saw (smooth and white), bdar (brown, dry and rough), and rdar (red, dry and rough). $S$. Typhimurium ATCC 14028 was used as the positive control for rdar morphology.

\section{Statistical Analyses}

Kruskal-Wallis test was used to calculate the significance of the differences between the biofilm formation abilities of the isolates on microtiter plates at different incubation times and temperatures $(p<0.05)$. The differences between average biofilm formations on polystyrene by the bdar and rdar morphotypes were analyzed by the Student's t-test $(\mathrm{p}<0.05)$. Spearman's correlation test was used to determine the association between biofilm formation of the isolates on microtiter plates and their pellicle formation abilities. Analyses were performed with Graphpad PRISM software (Intuitive Software for Science, San Diego, CA).

\section{Results and Discussion}

In the present study, biofilm formation abilities of food borne Salmonella isolates belonging to four different serovars (Infantis, Enteritidis, Kentucky and Telaviv) were determined on polystyrene microtiter plates at different temperatures representing routine food storage conditions, room temperature and optimum growth condition of Salmonella, respectively. The effect of incubation temperature and times on biofilm formation ability of the isolates on microtiter plates is shown in Fig. 1.

The hygienic status of food contact and processing surfaces is very important and determined by the ability of cells to adhere to surfaces (van Houdt \& Michiels, 2010). Polystyrene is a hydrophobic material and widely used in production of food contact, food packing and food service materials (Genualdi et al. 2014). 


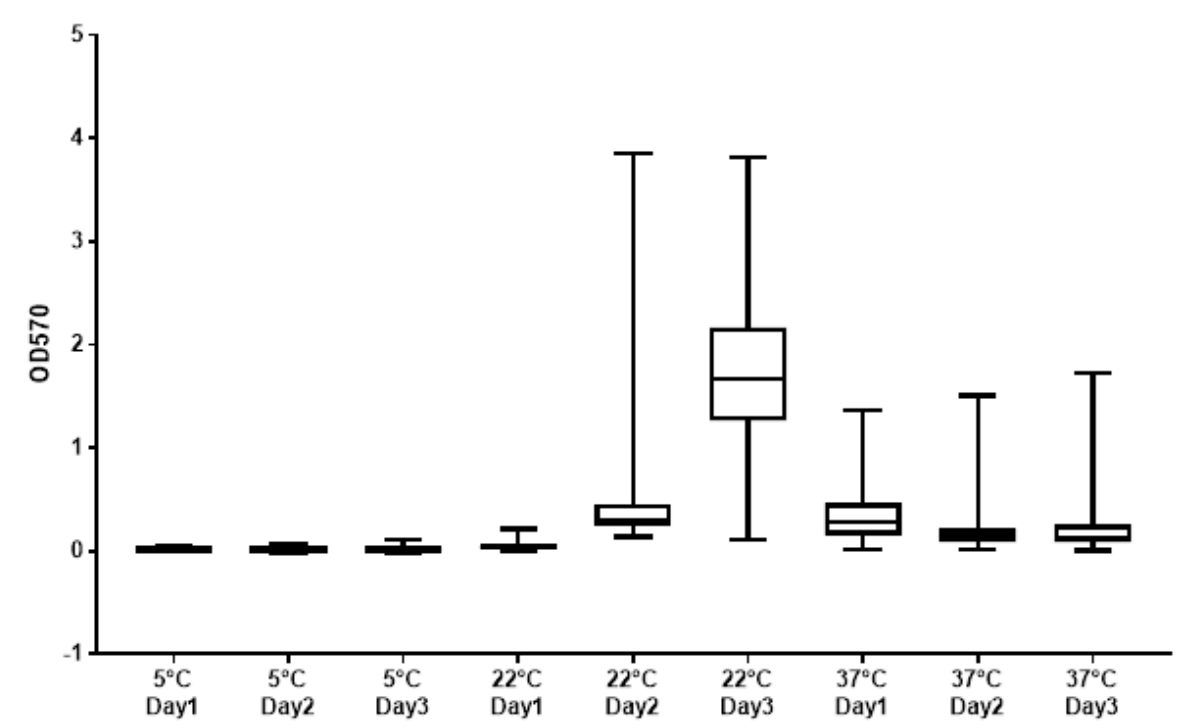

Fig. 1. The OD570 values of Salmonella isolates on microtiter plates at different incubation temperatures $\left(5^{\circ} \mathrm{C}, 22^{\circ} \mathrm{C}\right.$ and $\left.37^{\circ} \mathrm{C}\right)$ and incubation times (1,2 and 3 days). The OD value at $570 \mathrm{~nm}$ was used as the indication of level of biofilm formation.

Researchears commonly use microtiter plates as an in vitro mimic of the plastic surfaces in poultry production and daily use in houses (Díez-García et al. 2012, Piras et al. 2015, Borges et al. 2018). It has been previously showed that Salmonella spp. are capable of producing more biofilm on hydrophobic surfaces than hydrophilic surfaces (suchs as stainless steel, glass) (Sinde \& Carballo 2000, Donlan 2002, Cunliffe et al. 1999). In a similar manner, biofilm formation was determined for all of the Salmonella isolates at $22^{\circ} \mathrm{C}$ (day1 and day2). When the average biofilm formation of the isolates on microtiter plates were compared, the results showed that there was no significant difference between different incubation days at $5^{\circ} \mathrm{C}$ while the differences at $22^{\circ} \mathrm{C}$ were significant $(\mathrm{p}<0.05)$. When the incubation temperature was $37^{\circ} \mathrm{C}$, the difference between day1 and day2 was significant $(\mathrm{p}<0.05)$ but between day 2 and day 3 was not.

When the different incubation temperatures were compared based on a daily manner, the results revealed significant differences for all pairs for all days except $5^{\circ} \mathrm{C}$ and $22^{\circ} \mathrm{C}$ for day1. Biofilm forming abilities of bacteria depend on multiple factors one of which is the bacterial cell surface. For instance, in $S$. Typhimurium, expression of thin aggregative fimbriae was reported to increase at lower temperatures $\left(20\right.$ and $28^{\circ} \mathrm{C}$ ) (Römling et al. 1998). Increase in adherence to a surface at a low temperature may lead to persistence and survival in food-processing environments (Van Houdt and Michiels, 2010). It has been previously demonstrated that lower incubation temperature induced the biofim formation capacities of Salmonella serovars (Stepanović et al. 2003, Karaca et al. 2013, Milanov et al. 2017).

Accordingly, our results showed that the strongest biofilm formation capacities of the isolates were observed at $22^{\circ} \mathrm{C}$ for 3 days (Fig. 1.). At $37^{\circ} \mathrm{C}$ for 3 days, $22 \%$ of the isolates (Enteritidis and Infantis serovars) were determined as strong biofilm producers, 22\% (Infantis and
Kentucky serovars) were determined as moderate biofilm producers and $56 \%$ (Infantis and Telaviv serovars) were determined as weak biofilm producers. At $22^{\circ} \mathrm{C}$ (room temperature), $98 \%$ of the isolates (Enteridis, Infantis, Kentucky and Telaviv serovars) were determined as strong biofilm producers whereas only $2 \%$ (Enteritidis serovar) was determined as weak biofilm producers. At $5^{\circ} \mathrm{C}, 44 \%$ of the isolates (Enteritidis and Infantis serovars) were determined as weak biofilm producers and $56 \%$ (Infantis, Kentuck and Telaviv serovars) produced no biofilm. The lowest OD570 value $(0.001)$ was obtained in one of the Infantis isolates (A27) with the incubation at $5^{\circ} \mathrm{C}$ for 1 day and the highest OD570 value $(3,820)$ was obtained in the Telaviv isolate (A22) with the incubation at $22^{\circ} \mathrm{C}$ for 3 days. There are a few studies regarding the effects of incubation period and temperature on biofilm formation of Salmonella spp. strains. In a former study, Stepanović et al. (2003) studied with the serovars Enteritidis and Typhimurium, and showed that, although there was a significant difference in biofilm formed at $22^{\circ} \mathrm{C}$ incubation temperature after 24 and $48 \mathrm{~h}$ incubations, there was no significant difference when the temperature was set at $30^{\circ} \mathrm{C} / 37^{\circ} \mathrm{C}$ for the same incubation periods. More recently, Vestby et al. (2009b) tested the effect of incubation period on biofilm formation in microtiter plates using the serovar Typhimurium, Agona, Montevideo, Senftenberg strains and found that only the serovar Sefteenberg strains exhibited increased biofilm forming capacities for 2 and 4 days of incubation. In the present study, the effects of prolonged incubation period and different incubation temperatures were tested on biofilm formation in microtiter plates based on a serovar manner. Serovar Infantis, Enteritidis, Kentucky and Telaviv isolates were used, of which Infantis, Enteritidis and Kentucky serovars are among the most common isolated serovars in Turkey. Interestingly, Telaviv has also been commonly isolated from food samples in Turkey although it is among the rare serovars throughout 
the world (Ozdemir \& Acar 2014, Erol 1999, Durul et al. 2015). The results showed that both the prolonged incubation period and the temperature effected the biofilm formation capacities depending on the serovars. Serovar Infantis strains were the only serovars which showed significant increase in OD570 values from day one to day three for all incubation temperature conditions $\left(5^{\circ} \mathrm{C}, 22^{\circ} \mathrm{C}\right.$ and $37^{\circ} \mathrm{C}$ ). Serovar Telaviv and Kentucky strains showed significant increase only at $22^{\circ} \mathrm{C}$ and serovar Enteritidis strains showed significant increase only at $5^{\circ} \mathrm{C}$. It was suggested that at $22^{\circ} \mathrm{C}$, in the starionary phase of growth, utilization of nitrogen and phosphate induced the agfD promotor and contributed the multi-cellular state, but optimum growth condition $\left(37^{\circ} \mathrm{C}\right)$ caused faster changes in oxygen tension and $\mathrm{pH}$ and this situation had a negative effect on multicellular status of $S$. Typhimurium (Gerstel and Romling, 2001, Stepanović et al. 2003). The results obtained in the present study revealed the importance of evaluation of all these factors on a serovar basis. These results reveal the necessity of further and more detailed studies on biofilm formation capacities of different serovars and isolates.

Three different colony morphotypes (saw, bdar, and rdar) of the isolates were determined on CR Agar. rdar which is caused by the coexpression of curli fimbriae and cellulose is a typical colony morphology that was observed between biofilm producer isolates. bdar and saw morphotypes were determined with deletion mutation in csg genes required for curli fimbriae synthesis or in both csg and bcs genes coding for cellulose synthesis, respectively. The production of cellulose and curli fimbriae is important in biofilm formation and its persistence on various surfaces (Römling, 2000, Cookson et al. 2002, Solano et al. 2002). When incubated at $37^{\circ} \mathrm{C}$, $94 \%$ of the isolates exhibited bdar, $3 \%$ exhibited saw morphotype and one isolate belonging to the Infantis serovar presented a morphotype that has not been described previously. When the incubation temperature was $22^{\circ} \mathrm{C}, 81 \%$ and $19 \%$ of the isolates presented bdar and rdar morphotypes, respectively. On the other hand, isolates did not form biofilm on $\mathrm{CR}$ agar at low temperature $\left(5^{\circ} \mathrm{C}\right)$. bdar and rdar morphotypes were good biofilm producers and both morphotype were commonly detected in Salmonella strains but studies showed that rdar strain was more tolerant to long-term desiccation and nutrient depletion in biofilm when compared to the bdar strain. (Vestby et al. 2009a). Average biofilm formations on polystyrene by the bdar and rdar morphotypes at $22^{\circ} \mathrm{C}$ were determined as $1.483 \pm 0.098$ and $2.438 \pm 0.246$, respectively and the difference between the two OD values was statistically significant $(\mathrm{p}<0.05)$ (Fig. 2).

When the different morphotypes were evaluated in terms of the serovars, the bdar morphotype was found to be exhibited by $96 \%$ of the Infantis serovars while the Enteritidis, Kentucky and Telaviv serovars isolates exhibited the rdar morphotype. Also, a similar serovarmorphotype relation was determined in a former study (Karaca et al. 2013).

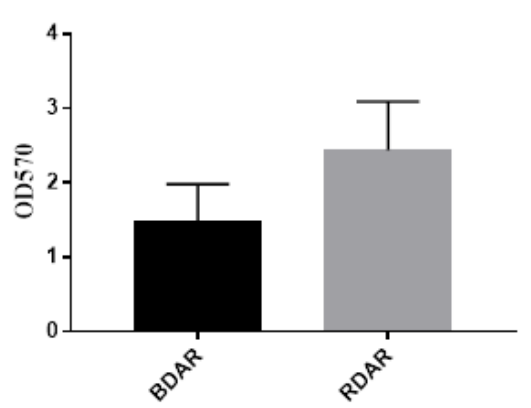

Fig. 2. Average biofilm formation on polystyrene of bdar and rdar strains.

Although all isolates formed pellicle at liquid-air interface at $22^{\circ} \mathrm{C}$, only $13 \%$ of the isolates belonging to the Infantis (A3, A16), Kentucky (A10) and Enteritidis (A13) serovars formed pellicle at liquid-air interface at $37^{\circ} \mathrm{C}$. No pellicle formation was detected at $5^{\circ} \mathrm{C}$. No correlation was determined between biofilm formation of the isolates on microtiter plates and their pellicle formation abilities $(r=0.1545, \mathrm{p}>0.05)$. rdar and bdar morphotyped isolates formed pellicle with rigid and fragile structures, respectively.

In a recent study, antibiotic resistance profiles of the isolates used in the present study were determined (Aksoy $\&$ Şen 2015). $81.3 \%$ of the isolates exhibited multiple antibiotic resistance and $S$. Kentucky (A10) and $S$. Enteritidis (A32) isolates were resistant to ciprofloxacin. Ciprofloxacin resistance is important because it is a common antibiotic choice for invasive salmonellosis in humans (Velhner et al. 2014). $67.75 \%$ of the isolates were found to have high pathogenicity potential in Caenorhabditis elegans nematode model system (Aksoy \& Şen 2015).

In a biofilm, avirulent and sensitive strains can become virulence and resistant via acquisition of virulence and resistance genes. It is also known that the rate of fluoroquinolone resistance of Salmonella strains was very low in Turkey (Albayrak et al. 2004, Ercis et al. 2006). However, fluoroquinolone resistance has recently become a common problem (Lin et al. 2015). High biofilm formation abilities of the present Salmonella strains can lead to widespread of virulence and resistance properties, especially to medically important antibiotics such as ciprofloxacin, via food chain. In addition, this situation constitutes an important public health concern. It is also known that biofilm formation abilities of Salmonella isolates are facilitated by long term persistence in food production environments (Vestby et al. 2009b). The present results suggested that almost all Salmonella isolates tested produced biofilm at room temperature. As a result, persistency of these isolates on abiotic surface increases which in turn increases cross contamination risk of the isolates. This can also be an explanation of widely distribution of Salmonella isolates in food. It is also an important public concern because poor sanitation of surfaces that comes in contact with food causes food borne outbreaks. This situation revealed the 
importance of microbial food safety and sanitation in industrial processes. Further investigations are required to investigate sanitation methods and effects of disinfectants on biofilms. An efficient and environmentally friendly control strategy is desired to better meet food safety and processing necessities, keeping in mind the fact that the resistance of biofilms to conventional disinfection processes is increased. In addition, interrupting the quorum sensing abilities of biofilm forming bacteria by

\section{References}

1. Aksoy, D. \& Şen, E. 2015. Investigation of pathogenic phenotypes and virulence determinants of foodborne Salmonella enterica strains in Caenorhabditis elegans animal model. Bulletin of Microbiology, 49(4): 513-524.

2. Albayrak, F., Cokca, F., Erdem, B. \& Aysev, A.D. 2004. Predictive value of nalidixic acid resistance for detecting salmonellae with decreased ciprofloxacin susceptibility. International Journal of Antimicrobial Agents, 23(4): 332-336.

3. Antunes, P., Mourão, J., Campos, J. \& Peixe, L. 2016. Salmonellosis: the role of poultry meat. Clinical Microbiology and Infection, 22(2): 110-121.

4. Borges, K.A., Furian, T.Q., Souza, S.N., Menezes, R., Tondo, E.C., Salle, C.T., Moraes H.L.S. \& Nascimento, V.P. 2018. Biofilm formation capacity of Salmonella serotypes at different temperature conditions. Pesquisa Veterinária Brasileira, 38(1): 71-76.

5. Cookson, A.L., Cooley, W.A. \& Woodward, M.J. 2002. The role of type 1 and curli fimbriae of Shiga toxinproducing Escherichia coli in adherence in abiotic surfaces. International Journal of Medical Microbiology, 292(3/4): 195.

6. Costerton, J.W., Stewart, P.S. \& Greenberg, E. P. 1999. Bacterial biofilms: a common cause of persistent infections. Science, 284(5418): 1318-1322.

7. Cunliffe, D., Smart, C.A., Alexander, C. \& Vulfson, E.N. 1999. Bacterial adhesion at synthetic surfaces. Applied and environmental microbiology, 65(11): 4995-5002.

8. Díez-García, M., Capita, R. \& Alonso-Calleja, C. 2012. Influence of serotype on the growth kinetics and the ability to form biofilms of Salmonella isolates from poultry. Food Microbiology, 31(2): 173-180.

9. Donlan, R.M. 2002. Biofilms: microbial life on surfaces. Emerging Infectious Diseases, 8(9): 881.

10. Durul, B., Acar, S., Bulut, E., Kyere, E. O. \& Soyer, Y. 2015. Subtyping of Salmonella food isolates suggests the geographic clustering of serotype Telaviv. Foodborne Pathogens and Disease, 12(12): 958-965.

11. Ercis, S., Erdem, B., Hasçelik, G. \& Gur, D. 2006. Nalidixic acid resistance in Salmonella strains with decreased susceptibility to ciprofloxacin isolated from humans in Turkey. Japanese Journal of Infectious Diseases, 59(2): 117.

12. Erol, İ. 1999. Ankara'da tüketime sunulan kiymalarda Salmonella'ların varlığı ve serotip dağılımı. Turkish Journal of Veterinary and Animal Science, 23(4): 321-5. natural biological agents may also be an affective option to solve biofilm related problems.

\section{Acknowledgement}

This study was presented as an oral presentation at XIII. Congress of Ecology and Environment with International Participation held on September 12-15 2017 in Edirne, Turkey.

13. Gerstel, U. \& Römling, U. 2001. Oxygen tension and nutrient starvation are major signals that regulate agfD promoter activity and expression of the multicellular morphotype in Salmonella typhimurium. Environmental Microbiology, 3(10): 638-648.

14. Genualdi, S., Nyman, P. \& Begley, T. 2014. Updated evaluation of the migration of styrene monomer and oligomers from polystyrene food contact materials to foods and food simulants. Food Additives \& Contaminants: Part A, 31(4): 723-733.

15. Hoelzer, K., Switt, A. I. M. \& Wiedmann, M. 2011. Animal contact as a source of human non-typhoidal salmonellosis. Veterinary Research, 42(1): 34.

16. Hoiby, N., Bjarnsholt, T., Givskov, M., Molin, S. \& Ciofu, O. 2010. Antibiotic resistance of bacterial biofilms. International Journal of Antimicrobial Agents, 35(4): 322332.

17. Karaca, B., Akcelik, N. \& Akcelik, M. 2013. Biofilmproducing abilities of Salmonella strains isolated from Turkey. Biologia, 68(1): 1-10.

18. Lin, D., Chen, K., Chan, E.W.C. \& Chen, S. 2015. Increasing prevalence of ciprofloxacin-resistant food-borne Salmonella strains harboring multiple PMQR elements but not target gene mutations. Scientific Reports, 5: 14754.

19. Milanov, D., Prunić, B., \& Ljubojević, D. 2017. Biofilm forming ability of Salmonella enterica serovar Tennessee isolates originating from feed. Veterinarski Arhiv, 87(6): 691-702.

20. Ozdemir, K. \& Acar, S. 2014. Plasmid profile and pulsedfield gel electrophoresis analysis of Salmonella enterica isolates from humans in Turkey. PloS One, 9(5): e95976.

21. Panisello, P.J., Rooney, R., Quantick, P.C. \& StanwellSmith, R. 2000. Application of foodborne disease outbreak data in the development and maintenance of HACCP systems. International Journal of Food Microbiology, 59(3): 221-234.

22. Piras, F., Fois, F., Consolati, S.G., Mazza, R. \& Mazzette, R. 2015. Influence of temperature, source, and serotype on biofilm formation of Salmonella enterica isolates from pig slaughterhouses. Journal of Food Protection, 78(10): 1875-1878.

23. Römling, U., Sierralta, W.D., Eriksson, K. \& Normark, S. (1998). Multicellular and aggregative behaviour of Salmonella typhimurium strains is controlled by mutations in the agfD promoter. Molecular Microbiology, 28(2): 249264.

24. Römling, U., Rohde, M., Olsén, A., Normark, S. \& Reinköster, J. 2000. AgfD, the checkpoint of multicellular 
and aggregative behaviour in Salmonella typhimurium regulates at least two independent pathways. Molecular Microbiology, 36(1): 10-23.

25. Shia, X. \&, Zhu, X. 2009. Biofilm formation and food safety in food industries. Trends in Food Science \& Technology, 20(9): 407-413.

26. Sinde, E. \& Carballo, J. 2000. Attachment of Salmonella spp. and Listeria monocytogenes to stainless steel, rubber and polytetrafluorethylene: the influence of free energy and the effect of commercial sanitizers. Food Microbiology, 17(4): 439-447.

27. Solano, C., García, B., Valle, J., Berasain, C., Ghigo, J. M., Gamazo, C. \& Lasa, I. 2002. Genetic analysis of Salmonella enteritidis biofilm formation: critical role of cellulose. Molecular Microbiology, 43(3): 793-808.

28. Srey, S., Jahid, I.K. \& Ha, S.D. 2013. Biofilm formation in food industries: a food safety concern. Food Control, 31(2): 572-585.

29. Steenackers, H., Hermans, K., Vanderleyden, J. \& De Keersmaecker, S.C. 2012. Salmonella biofilms: an overview on occurrence, structure, regulation and eradication. Food Research International, 45(2): 502-531.

30. Stepanović, S., Vuković, D., Dakić, I., Savić, B. \& ŠvabićVlahović, M. 2000. A modified microtiter-plate test for quantification of staphylococcal biofilm formation. Journal of Microbiological Methods, 40(2): 175-179.

31. Stepanović, S., Ćirković, I., Mijač, V. \& Švabić-Vlahović, M. 2003. Influence of the incubation temperature, atmosphere and dynamic conditions on biofilm formation by Salmonella spp. Food Microbiology, 20(3): 339-343.

32. Stepanović, S., Ćirković, I., Ranin, L. \& Svabić-Vlahović, M. 2004. Biofilm formation by Salmonella spp. and Listeria monocytogenes on plastic surface. Letters in Applied Microbiology, 38(5): 428-432.

33. Turki, Y., Ouzari, H., Mehri, I., Aissa, R.B. \& Hassen, A. 2012. Biofilm formation, virulence gene and multi-drug resistance in Salmonella Kentucky isolated in Tunisia. Food Research International, 45(2): 940-946.

34. Van Houdt, R. \& Michiels, C. W. 2010. Biofilm formation and the food industry, a focus on the bacterial outer surface. Journal of Applied Microbiology, 109(4): 11171131.

35. Velhner, M., Kozoderović, G., Grego, E., Galić, N., Stojanov, I., Jelesić, Z., \& Kehrenberg, C. 2014. Clonal spread of Salmonella enterica serovar Infantis in Serbia: Acquisition of mutations in the topoisomerase genes gyrA and parC leads to increased resistance to fsluoroquinolones. Zoonoses and Public Health, 61(5): 364-370.

36. Vestby, L.K., Møretrø, T., Ballance, S., Langsrud, S., \& Nesse, L.L. 2009a. Survival potential of wild type cellulose deficient Salmonella from the feed industry. BMC Veterinary Research, 5(1): 43.

37. Vestby, L.K., Møretrø, T., Langsrud, S., Heir, E., \& Nesse, L.L. 2009b. Biofilm forming abilities of Salmonella are correlated with persistence in fish meal-and feed factories. BMC Veterinary Research, 5(1): 20. 